\title{
New Phonological Representation of Children with Speech Sound Disorders
}

\author{
Se-Ryeong Bae ${ }^{\mathrm{a}}$, Ji-Wan Ha ${ }^{\mathrm{b}, \mathrm{c}}$, Min-Mo Koo ${ }^{\mathrm{d}}$, Yu Mi Hwang ${ }^{\mathrm{c}, \mathrm{e}}$, Sung-Bom Pyun ${ }^{\mathrm{f}, \mathrm{g}}$ \\ ${ }^{a}$ Department of Rehabilitation Science, Graduate School, Daegu University, Gyeongsan, Korea \\ ${ }^{b}$ Department of Speech Pathology, Daegu University, Gyeongsan, Korea \\ 'International Institute of Rehabilitation Science, Daegu University, Gyeongsan, Korea \\ ${ }^{d}$ Biomedical Research Center, Korea University Anam Hospital, Seoul, Korea \\ ${ }^{e}$ Research Institute for Language \& Information, Korea University, Seoul, Korea \\ ${ }^{f}$ Department of Physical Medicine and Rehabilitation, Korea University College of Medicine, Seoul, Korea \\ ${ }^{8}$ Brain Convergence Research Center, Korea University Anam Hospital, Seoul, Korea
}

Correspondence: Ji-Wan $\mathrm{Ha}, \mathrm{PhD}$ Department of Speech Pathology, Daegu University, 201 Daegudae-ro, Jillyang-eup, Gyeongsan 38453, Korea

Tel: $+82-53-850-4327$

Fax: $+82-53-850-4329$

E-mail: jw-ha@daegu.ac.kr

Received: January 5, 2016

Revised: February 10, 2016

Accepted: February 15, 2016

This work was supported by the National Research Foundation of Korea Grant funded by the Korean Government (NRF-2013S1A3A2043454).
Objectives: To determine if the phonological representation (PR) deficit of children with speech sound disorders (SSD) begins in the initial stage of PR, this study compared the ability to learn new PR between SSD children and typically developing children (TD). Methods: The study subjects were 14 SSD children and 19 TD children 4, 5, and 6 years of age. After the learning stage, a new PR judgment and retrieval tasks were performed, measuring the accuracy and reaction time of responses. The relationships among age, accuracy of articulation, receptive vocabulary, and task performances were examined. Results: In terms of correct response score on the new PR judgment task, SSD children were significantly lower than TD children. SSD children and TD children had no significant difference in reactions time. With regard to accuracy of the new PR retrieval task, both SSD children and TD children had difficulty with the retrieval of new PR, and thus there was no significant difference. It was found that there were significant correlations between the performance of the new PR judgment task and accuracy of articulation, between the performance of the new PR retrieval task and receptive vocabulary, and between age and both tasks. Conclusion: The study results indicate that SSD children have more difficulty memorizing new PR accurately than TD children. PR deficit of SSD children is likely to begin in the initial stage of PR.

Keywords: Judgement task of new phonological representation, Retrieval task of new phonological representation, Speech sound disorders
Diagnostic and Statistical Manual of Mental Disorders-5 (DSM5; American Psychiatric Association, 2013)에서는 말소리장애 (speech sound disorders)를 구어 의사소통을 방해하는 지속적인 불명료한 말산출로 인해, 사회적 참여, 학업적 성취, 또는 직업적 수 행에 제한을 야기하는 장애로 정의하였다. 덧붙여 뇌성마비, 구개 열, 난청, 청력소실, 외상뇌손상 또는 기타 다른 의학적, 신경학적 원 인으로 인한 경우는 제외하고, 원인을 모르는 경우에만 국한하여 ‘말소리장애’로 진단할 것을 권고하였다. 그러나 이때에도 원인을 '모른다'는 것이지, 원인이 '없다'는 것은 아니다. 따라서 원인 모르 는 말소리장애의 원인을 밝혀내기 위한 노력이 국내외 연구들에서
활발하게 진행되고 있다. 이러한 연구들의 공통된 입장은 말소리 장애는 하나의 원인으로 발생하는 것이 아니며, 여러 유형의 원인 들이 존재한다는 것이다. 그렇지만 장애의 일차적 원인들을 찾아 내는 것은 매우 요원한 작업이기 때문에, 그 대안책으로 말소리장 애의 여러 하위집단들을 분류하거나 말소리장애에 영향을 주는 기 저요인들을 찾아내는 연구들이 이루어지고 있다. 말소리장애를 하 위집단들로 나누고 각 집단이 가지고 있는 기저 공통요인을 찾아내 거나 또는 말소리장애 집단이 보이는 기저 공통점을 찾아낸 후 그 공통요인을 바탕으로 집단을 분류한다면, 그것은 간접적으로나마 말소리장애의 일차적 원인들에 접근해가는 방법일 것이다. 원인 모 
르는 말소리장애의 보다 명확한 원인들을 밝혀내기 위해, 앞으로 도 이와 같은 주제에 대한 연구는 지속적으로 필요할 것이다(Kim \& Shin, 2015).

말소리장애의 관련요인들 가운데 본 연구에서는 음운표상(phonological representation)에 관한 것을 다루고자 한다. 음운표상은 장기기억에 저장되어 있는 단어의 음운정보이다(Sutherland, 2006). 음운표상의 음운정보는 단어의 음소와 음성 수준의 모든 정보들 을 포함하고 있는 것으로, 해당 단어를 다른 단어와 변별할 수 있도 록 말소리와 같은 청각정보뿐 아니라 여기에 동반되는 시각정보, 예 를 들어 입술움직임과 같은 정보까지도 포함하고 있는 것으로 설명 된다(Stackhouse \& Wells, 1997). 어휘재구조화(lexical restructuring) 가설(Walley, 1993)에 의하면, 단어를 통단어 형태로 어휘저장 소에 저장하던 어린 연령의 아동들은 어휘폭발기에 이르러 단어의 양이 폭발적으로 증가하면서 통단어 형태의 저장에 어려움을 겪게 된다. 따라서 그 이후 통단어를 음절, 음소 단위로 분절하여 저장하 게 되고, 이러한 과정을 통해 음운표상이 더욱 정교하고 명확하게 발달한다(Claessen, Heath, Fletcher, Hogben, \& Leitão, 2009). 아동 의 음운표상 발달은 1 세경 나타나는 초기 형태의 발달을 시작으로 (Sutherland \& Gillon, 2005; Walley, 1993), 8세경 성인 수준의 정교 한 형태로 완성된다고(Claessen et al., 2009) 보고되었다.

음운표상은 '단어' 수준의 말소리 정보이지, 개별 ‘음소' 차원의 말소리 정보는 아니라는 것을 명심하여야 할 것이다. 앞에서도 설 명하였듯이, 음운표상이 가지고 있는 모든 정보들은 해당 단어를 다른 단어들과 변별하기 위한 것이다. 예를 들어 '가방'이라는 단어 에서 그 단어가 가지고 있는 $/ \mathrm{k} /, / \mathrm{\alpha} /, / \mathrm{p} /, / \mathrm{\alpha} /, / \mathrm{n} /$ 의 일련의 소리정보 묶음을 음운표상이라 하고, $/ \mathrm{k} /$ 와 $/ \mathrm{\alpha} /$ 같은 각 음소들의 개별적 소 리정보는 음운표상이 아니다. 단어 차원의 정보이기 때문에, 음운 표상은 장기기억에 저장되어 있는 단어들의 소리형태(lexeme)에 대한 지식이라고 할 수 있다. 이와 같은 이유로, Stackhouse와 Wells (1997)의 말처리 모델(speech processing model)에서도 음운표상 은 어휘저장소에 위치하고 있다.

단어의 말소리를 정상적으로 산출하기 위해서는, 장기기억 속음 운표상의 자체에도 결함이 없어야 하고 이것과 관련한 처리과정에 도 문제가 없어야 한다(Kim \& Ha, 2014). 따라서 음운표상이 명확 하고 변별적이고 안정적으로 저장되어 있지 않은 경우(Anthony et al., 2010), 혹은 음운표상의 저장에는 문제가 없더라도 그것의 접근 또는 인출에 문제가 있는 경우(Sutherland, 2005) 말소리장애가 초 래될 수 있다. 말소리장애아동은 음운표상이 명확하지 않고 그것 을 인출하는 능력에 결함이 있음을 보고한 연구(Kim \& Ha, 2014; Sutherland \& Gillon, 2007), 음운표상을 바탕으로 하는 음운인식
과제에서 말소리장애아동의 어려움을 밝힌 연구(Claessen \& Leitão, 2012; Jung, Choi, \& Ha, 2015), 음운표상과 말산출 능력 또 는 조음정확도의 밀접한 관련성을 보고한 연구(Carroll \& Snowling, 2004; Sutherland \& Gillon, 2007) 등은 모두 말소리장애와 관 련한 기저요인으로 음운표상 결함의 가능성을 제안하고 있다.

그러나 앞에서 살펴보았던, 말소리장애아동의 현 시점에서의 음 운표상 결함에 대한 연구들은 그것의 구체적 발생단계에 대해서는 해답을 제시하지 못하였다. 즉, 말-언어발달과 관련하여 음운표상 의 결함이 어느 단계에서부터 발생하였는지에 대해서는 명확하게 언급하고 있지 않다. 음운표상 결함의 발생단계로 다음과 같은 몇 가지 가능성을 생각해볼 수 있다. 첫째, 음운표상의 초기 형성단계 에서 저장이 제대로 이루어지지 않았을 경우, 둘째, 저장은 정상적 으로 이루어졌으나 장기기억에서 음운표상을 유지하는 데에 결함 이 있을 경우, 셋째, 장기기억 속 음운표상에는 문제가 없으나 그것 에 접근, 인출하는 단계에서 결함이 발생하였을 경우를 가정해 볼 수 있다. 이 가운데 초기 형성단계의 문제는 그 이후 두 번째와 세 번째 단계에도 부정적 영향을 줄 것이다. 음운표상의 유지, 접근, 인 출이 정상적으로 이루어지기 위해서는 초기 형성단계에서 정상적 인 입력과 저장이 전제되어야 하기 때문이다. 본 연구에서는 말소 리장애아동의 음운표상 결함 시점을 유추하기 위하여 새롭게 접 한 음운표상의 입력, 저장, 인출이 정상적으로 이루어지는지를 살 펴보고, 초기 음운표상 형성단계의 결함 가능성 여부를 알아보고 자 하였다. 만일 말소리장애아동이 새로운 음운표상의 저장 또는 인출에 문제를 보인다면 음운표상 초기 형성단계부터 그 결함이 초래되었을 가능성을, 그렇지 않다면 장기기억 속에서 음운표상을 유지하거나 그것에 접근, 인출하는 단계에서 문제가 발생하였을 가 능성을 생각해 볼수 있다.

새로운 자극이 입력되면 장기기억 속 항목 중 이와 유사한 음운 형태의 단어를 찾게 되고 기존의 단어는 새로운 단어자극을 지각, 저장, 인출하는 데에 긍정적인 영향을 준다(Kim \& Ha, 2014). 새로 운 음운표상의 단어유사성 정도가 음운기억과 관련한 과제수행에 영향을 미치는 이유가 바로 이 때문이다. 즉, 단어유사성이 높은 새 단어는 그렇지 않은 새 단어에 비해 더 쉽게 기억될 수 있다. 이와 더 불어 각 대상아동이 보유하고 있는 어휘량이 과제수행에 미칠 영 향에 대해서도 생각해보아야 할 것이다. 어휘량이 많은 아동은 새 롭게 접하는 소리자극에 대해 그와 유사한 형태의 기존 단어를 떠 올릴 기회가 많은 반면, 어휘량이 적은 아동은 떠올릴 만한 단어가 한정적이다. 따라서 어휘가 풍부하면 결과적으로 새로운 음운표상 의 단어유사성이 높아질 가능성이 커진다. 본 연구를 진행하기 위 해서는 새로운 음운표상, 즉 어떤 한국어 단어와도 동일하지 않는 
소리구조를 가지는 '비단어'를 제작하는 과정이 우선적으로 이루 어져야 했다. 비단어 제작 시에는 단어유사성과 어휘량을 모두 고 려하여야 할 것인데, 대상 아동들은 어휘량을 완전히 통제하는 것 은 현실적으로 불가능하다. 따라서 본 연구에서는 단어유사성이 낮은, 때문에 어떠한 대상아동들에게도 어휘저장소에 그와 유사 한 단어의 형태가 저장되어 있을 가능성이 낮은 비단어들을 이용 하여 새로운 음운표상 과제를 제작하였다.

비단어를 새로운 음운표상으로 만들어주기 위해서는 그것에 의 미가 더해져야 한다. 새로운 소리조합인 비단어에 의미가 연결될 때, 비로소 아동의 어휘저장소에 그 '비단어'는 '새 단어'로 자리잡 게 되고 음운표상으로서의 실체도 갖게 된다. 따라서 본 연구에서 는 현실에 존재하지 않는 캐릭터 또는 사물의 형상을 그림으로 제 작하여 이것을 해당 비단어와 반복 연결시키는, 즉 새 말소리와 새 의미를 결부시키는 학습단계를 거친 후, 그것의 저장 및 인출능력 을 살펴보고자 하였다. 이때 음운표상의 저장상태는 음운표상 판 단과제를, 음운표상 인출능력은 이름대기 과제를 이용하여 알아보 았다. 새로운 음운표상 판단과제는 그림과 소리자극을 동시에 제 시한 후, 대상자로 하여금 제시한 소리형태가 학습단계에서 해당 그림과 함께 들었던 그 소리자극이 맞는지, 틀린 지를 판단하는 수 용기반 과제이다. 이때 소리자극은 각 그림에 해당하는 새로운 음 운표상이거나, 또는 그것과 음운적으로 약간의 차이가 있는 틀린 소리자극이다. 학습단계를 거쳐 새롭게 형성된 음운표상이 정확하 게 저장되어 있는 아동은 그렇지 않은 아동에 비해 새로운 음운표 상 판단과제의 수행력이 좋을 것이다. 새로운 음운표상 인출과제는 구어산출과정을 포함한 그림이름대기 과제이다. 대상아동에게 학 습단계에서 익혔던 그림을 제시한 후 그것의 이름을 말하게 함으로 써, 새로운 음운표상 인출능력을 알아보고자 하였다.

본 연구의 목적은 말소리장애아동과 일반아동을 대상으로 새로 운 음운표상 판단과제의 정반응 점수와 반응시간 그리고 새로운 음운표상 인출과제의 정확도를 비교하여, 말소리장애아동에서 새 로운음운표상 형성능력을 살펴보고자 하는 것이다. 그리고 주요변 인들 간 상관관계 분석을 통하여 새로운 음운표상 형성과 관련이 있는 요인들을 찾아보고자 하였다. 이와 같은 본 연구의 연구질문 들을 정리해보면 다음과 같다. 첫째, 말소리장애아동 집단과 일반 아동 집단 간 새로운 음운표상 판단과제의 정반응 점수와 반응시 간에 유의한 차이가 있는가? 둘째, 말소리장애아동 집단과 일반아 동 집단 간 새로운 음운표상 인출 정확성에 차이가 있는가? 셋째, 월령, 수용어휘력, 자음정확도와 새로운 음운표상 판단과제 및 인 출과제 수행력과 각각 상관이 있는가? 또한 새로운 음운표상 판단 과제 수행력과 인출과제 수행력 간 상관이 있는가?

\section{연구 방법}

\section{연구대상}

본 연구는 $4,5,6$ 세 말소리장애아동 14 명과 일반아동 19 명을 대 상으로 하였다. 이와 같은 연령의 아동을 대상으로 선정한 이유는 어휘발달이 급증하는 동시에 음운표상도 활발하게 발달하는 시기 라는 선행연구(Claessen et al., 2009)에 근거하여, 음운표상 형성능 력의 발달양상에 대해 보다 명료하게 살펴보고자 하기 위함이었다. 말소리장애 집단의 선정기준은 다음과 같다. 첫째, 부모와 교사의 보고에 의해 감각적, 신경학적, 그 외 신체적인 결함이 없고 인지적, 언어적 문제가 없는 아동, 둘째, 수용-표현어휘력검사(REVT; Kim, Hong, Kim, Jang, \& Lee, 2009) 결과 수용어휘력이 -1 SD 이상 범위 에 속하는 아동, 셋째, 우리말 조음·음운평가(U-TAP; Kim \& Shin, 2004) 결과 단어 수준에서 자음정확도가 - $2 \mathrm{SD}$ 이하에 속하는 아 동들을 대상으로 하였다. 모든 대상자들은 언어장애전문가에 의 해 말소리장애로 진단받았으나 조음기관의 구조적 장애는 지니고 있지 않은 아동들이었다. 일반아동의 선정기준은 다음과 같다. 첫 째, 부모와 교사의 보고에 의해 감각적, 신경학적, 그 외 신체적인 결 함이 없고 인지적, 언어적 문제가 없는 아동, 둘째, REVT 결과수용 어휘력 능력이 -1 SD 이상 범위에 속하는 아동, 셋째, 우리말 U$\mathrm{TAP}$ 결과 단어 수준에서 자음정확도가 -1 SD 이상 범위에 속하는 아동들을 대상으로 하였다.

본 연구에서 실시한 새로운 음운표상 판단과제와 인출과제는 모 두 구어자극의 입력절차를 통하여 이루어진다. 때문에 본 실험결과 가 순수하게 대상자들의 새로운 음운표상 형성능력을 반영하기 위 해서는 두 집단 간 말지각 능력에 차이가 없어야 한다. 또한 새로운 음운표상을 학습, 형성하기 위해서는 구어자극을 일시적으로 보유 할 수 있는 청각적 단기기억력이 전제되어야 한다. 따라서 본 연구 에서는 자음변별검사(Kwon, 2004)와 숫자 바로따라하기 검사 (Kwak, Oh, \& Kim, 2011)를 실시하여, 대상자들의 말지각 능력과 단기기억력을 통제하였다.

이와 같은 과정을 통하여 대상아동들을 선정한 결과, 말소리장 애 집단은 남아 8 명, 여아 6 명, 일반 집단은 남아 10 명, 여아 9 명이었 고, 평균 연령은 말소리장애 집단 60.29 (8.24)개월, 일반 집단 64.05 (7.75)개월이었다. 두 집단 간 성별과 연령에 통계적으로 유의한 차 이가 없었다 $(p>.05)$. 또한 자음변별검사에서 말소리장애집단 평균 31.29 (6.23)점, 일반 집단 평균 29.95 (3.17)점으로, 두 집단 간 유의 한 차이가 없었고 $(t=.736, p>.05)$, 숫자 바로따라하기 검사에서 말 소리장애집단 평균 8.86 (2.21)점, 일반집단 평균 10.26 (1.66)점으로 집단 간 차이가 유의하지 않았다 $(t=-1.998, p>.05)$. REVT 결과 수 
용어휘력능력도 말소리장애집단 59.79 (13.46)점, 일반집단 66.74 (15.67)점으로 그 차이가 유의하지 않았다 $(t=-1.366, p>.05)$. 단지 두 집단은 U-TAP검사에서만 유의한 차이를 보였는데 $(t=-6.755$, $p<.01)$, 평균 자음정확도는 말소리장애집단 $79.36 \%$ (9.98\%), 일반 집단 $97.79 \%(2.46 \%)$ 였다.

\section{실험 과제 제작}

\section{새로운 음운표상 선정 및 그림 제작}

새로운 음운표상 과제에 사용될 목표 음운표상으로 Lee, Ha, Koo, Hwang과 Pyun (2016)의 연구에서 제작되었던 비단어 중 2음 절어 5 개와 3 음절어 3 개를 선택하였다. 이 중 2 음절어 2 개는 연습항 목에 사용되었다. 선정된 8 개의 비단어에 대하여 언어치료학 전공 대학생 130명을 대상으로 5점 척도(1점: 단어와 매우 유사하지 않 다-5점: 단어와 매우 유사하다)의 평정법을 이용하여 단어유사성 검사를 실시하였다. 모든 비단어가 2.50점 이하(평균 2.02점)로 평 가되어, 단어유사성 정도는 낮은 것으로 간주할 수 있다. 그리고 100 만음절 말뭉치 자료(Kim \& Kang, 1997)에 근거하였을 때, 선정 된 8개 비단어의 각 평균 음절빈도는 300 이상으로 모두 고빈도 음 절들로 구성되었음을 알 수 있다. 새로운 음운표상으로 사용될 비 단어 목록은 Table 1 과 같다.

각 비단어와 연결시킬 그림제작을 위하여, 전문 일러스트레이터 에게 현실에 존재하지 않는 캐릭터 또는 사물을 창의적으로 그려 줄 것을 의뢰하였다. 여러 차례 수정과정을 거쳐 캐릭터 형상 3 개, 사물 형상 5 개의 그림이 최종 제작되었고, 이 중 2 개는 연습항목에, 5 개는 본 실험에 사용하였다(Appendix 1).

\section{학습과제 제작}

새로운 음운표상 학습을 위해 각 그림과 함께 목표 음운표상이 청각적으로 반복 제시되는 MS 파워포인트 슬라이드를 제작하였 다. 목표 음운표상은 해당 비단어가 단독으로 제시되거나 또는 그 것을 포함한 문장이 제시되었다. 예를 들어 "너겝", "이것은 너겝이 야", "작은 너겝", "너겝은 귀여워", "너겝은 콧수염이 있어", "너겝 은 갈색이야"와 같은 녹음된 음성자극이 각 음운표상에 대해 6차 례씩 제시되었다(Appendix 2). 모든 음성자극은 전문 아나운서가 방음실에서 녹음하였다. 목표 음운표상당 학습기회가 6회씩 제공
되었으며, 따라서 학습단계에서 사용된 슬라이드는 총 48 장으로 구성되어 있다.

\section{전산화된 새로운 음운표상 판단과제 제작}

새로운 음운표상 판단과제는 음운표상의 질(quality)을 알아보 는 과제로, 그림과 자극어를 동시에 제시한 후 제시한 자극어가 해 당 그림에 대한 음운표상이 맞는지, 틀린 지를 판단하는 과제이다. 따라서 틀린 자극어 제작을 위해 해당 음운표상에 대한 말소리 조 작과정이 필요하였다. 마지막 음소보다 첫 음소를 조작하였을 때 음운표상 판단과제 수행력이 더 좋다는 선행연구(Walley, 1993)에 근거하여, 조작된 말소리는 목표 음운표상 첫 음절의 자음, 모음 또 는 자음+모음을 변형시켜 제작하였다. 첫 음절 자음조작을 위해 목표 자음과 같은 조음위치의 다른 조음방법, 또는 같은 조음위치 의 다른 발성유형의 자음으로 바꾸었다. 그리고 첫 음절 모음조작

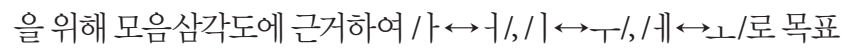
모음과 최대한 인접한 소리로 연구자가 임의로 설정하여 바꾸었다. 이러한 과정으로 새로운 음운표상 각각에 대해 3 개씩의 조작된, 틀 린 자극어가 완성되었다(Appendix 3). 모든 자극어는 전문 아나운 서가 방음실에서 녹음하였다.

전산화된 새로운 음운표상 판단과제는 E-Prime으로 제작하였 다. 우선 노트북 모니터에 준비화면이 제시되면 검사자는 대상자의 주의를 환기시킨 후 마우스를 클릭한다. $500 \mathrm{~ms}$ 의 inter-stimulus interval (ISI) 이후 그림이 화면에 나타남과 동시에 자극어가 청각적 으로 제시된다. 대상자가 $\mathrm{O}, \mathrm{X}$ 에 해당하는 반응키를 누르면 $500 \mathrm{~ms}$ 의 inter-trial interval (ITI) 이후 바로 다음 항목으로 넘어간다. 새로 운 음운표상 자극어 6 개를 3 회씩 반복하였기 때문에, 정확한 항목 은 총 18 회 제시되었다. 그리고 6 개의 음운표상에 대해 3 개씩 말소리 를 조작하였기 때문에, 조작된, 틀린 자극어 또한 동일하게 총 18 회 제시되었다. 항목은 무작위 순서로 제시되었고, 반응시간은 자극어 가 제시된 직후부터 대상자가 반응키를 누르는 순간까지 자동으로 측정되었다. 새로운음운표상 판단과제 구성 예는 Figure 1과 같다.

\section{실험절차}

조용하고 독립된 공간에서 연구자 1 인과 일대일로 진행하였다. 실험순서는 목표단어 학습단계, 새로운 음운표상 인출과제, 새로

Table 1. A list of new phonological representations

\begin{tabular}{|c|c|c|c|c|c|c|c|c|}
\hline \multirow[b]{2}{*}{ Non-word form } & \multicolumn{2}{|c|}{ Practice items } & \multicolumn{6}{|c|}{ Test items } \\
\hline & nipun & hinuk & $\mathrm{n} \Lambda \mathrm{kep}$ & $\operatorname{nip} \wedge k^{*} \Lambda \eta$ & teluupt ${ }^{*}$ up & $\mathrm{m} \Lambda \mathrm{k \varepsilon mmin}$ & tupip & $m \Delta t^{h} u l$ \\
\hline Wordlikeness & 2.35 & 2.12 & 2.50 & 1.92 & 1.38 & 1.56 & 2.35 & 2.43 \\
\hline Syllable frequency & 3,005 & 988 & 332 & 3,512 & 1,333 & 469 & 975 & 473 \\
\hline
\end{tabular}




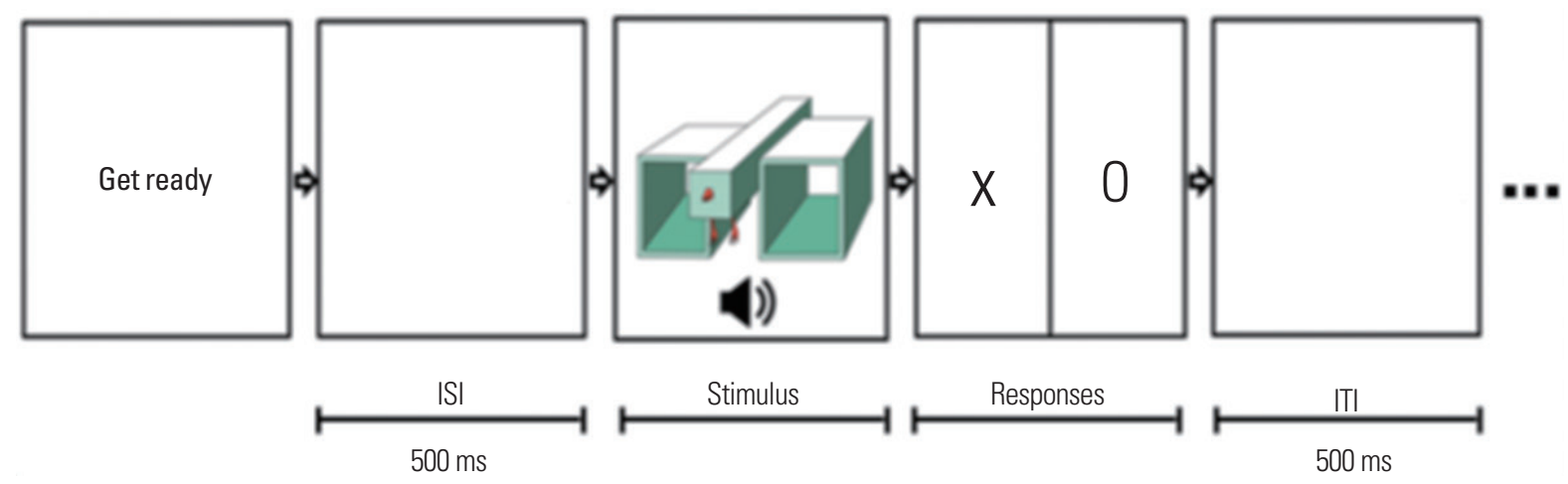

Figure 1. Computerized new phonological representation task. ISI = inter-stimulus interval; $I T \mid=$ inter-trial interval.

운 음운표상 판단과제 순으로 이루어졌다. 새로운 음운표상 판단 과제 시 틀린 자극어가 제시되기 때문에, 이로 인해 아동들이 음운 표상을 혼돈할 가능성이 있어 판단과제보다 인출과제를 먼저 실시 하였다. 학습단계에서 연구자는 대상아동에게 "이 세상에 존재하 지 않는 새로운 괴물을 보여주고, 그 이름을 알려줄 거예요. 이름을 잘 기억하고 있다가 나중에 선생님한테 말해주세요.”라고 설명하 였다. 연습항목을 포함한 총 8 개의 그림에 대해 각 6 회씩 학습제시 어가 제시되어, 아동들은 해당 그림과 음운표상을 짝지어 새로운 단어를 6차례씩 접할 기회를 가졌다. 학습단계의 총 소요시간은 약 7분이었다.

학습단계가 끝난 후 그림을 제시하고 그것의 이름을 말하게 하 는 새로운 음운표상 인출과제를 실시하였다. 인출과제의 그림자극 은 학습단계에서 사용한 것과 동일한 것이었다. 연구자는 아동에 게 “컴퓨터 화면을 보면 그림이 나올 거예요. 그 그림의 이름을 말 해주세요."라고 지시하였다. 본 실험에 앞서 연습항목의 인출과제 를 실시하였고, 과제진행 동안 연구자는 아동에게 아무런 피드백 을 제공하지 않았다. 충분한 시간을 주어도 아동이 아무런 반응을 하지 않을 경우, 아동의 의사를 확인한 후 다음 그림으로 넘어갔다. 인출과정의 모든 과정은 녹음기에 녹음되었다.

인출과제가 끝난 후 새로운 음운표상 판단과제를 실시하였다. 판 단과제는 화면에 그림과 자극어가 함께 제시되고, 그 자극어가 학습 단계에서 들었던 것과 동일한 것이면 $\mathrm{O}$ 버튼을, 다른 것이면 $\mathrm{X}$ 버튼 을 빠르게 누르는 과제이다. 연구자는 “컴퓨터 화면을 보면 그림이랑 말소리가 함께 나올 거예요. 잘 듣고 그림이랑 말소리가 맞으면 '초록 동그라미(키보드 A키)', 틀리면 '빨간 엑스(키보드 L키)'를 눌러주세 요. 한 번만 들려주니 집중해서 잘 들어야 해요."라고 지시하였다. 모 든 대상자들은 헤드폰을 통해 자극어를 들었고, 소리크기는 동일하 게 제시하였다. 연습항목을 이용하여 아동에게 정확하게 자판을 누 르는 방법 등을 충분히 연습시킨 후 본 실험을 시작하였다.

\section{자료처리 및 통계분석}

새로운 음운표상 판단과제는 목표 그림이 화면에 제시된 순간부 터 아동이 반응키를 누르는 순간까지의 정오반응과 반응시간이 프 로그램에 자동으로 기록되었다. Maillart, Schelstraete와 Hupet (2004)의 신호탐지이론(signal detection rationale)에 근거하여, 새 로운 음운표상 판단과제의 반응을 맞는 자극어를 맞다고 반응한 경우(Hit), 맞는 자극어를 틀리다고 반응한 경우(Miss), 틀린 자극 어를 맞다고 반응한 경우(False alarm), 틀린 자극어를 틀리다고 반 응한 경우(Correct rejection)의 4 가지 유형으로 분류하였다. 이 중 정반응은 Hit와 Correct rejection으로, 본 연구에서는 두 유형의 정반응을 구분하여 점수화하였다. 새로운 음운표상 6개에 대해 각 각 3 회씩의 정확한 말소리 항목과 조작된 말소리 18 항목이 제시되 기 때문에, Hit와 Correct rejection은 모두 18점을 만점으로 한다.

새로운 음운표상 판단과제의 반응시간은 속도-정확성의 교환효 과(speed-accuracy trade-off effect) (Townsend \& Ashby, 1983)를 고려하여 분석하였다. 속도-정확성의 교환효과에 의하면, 대상자 가 반응을 빨리 하면 오반응이 많아지고 반응을 천천히 하면 정반 응이 증가하게 된다. 즉 정확한 반응을 위해서는 처리에 필요한 시 간이 더욱 요구되기 때문에, 반응시간은 늦어질 수 밖에 없다는 것 이다. 대상자의 반응 중 오류가 $15 \%$ 이상이면 속도-정확성의 교환 효과가 결과에 반영되기 때문에, 반응시간을 그대로 분석하는 것 은 타당하지 않다(Bruyer \& Brysbaert, 2011). 따라서 본 연구에서 는 속도-정확성의 교환효과를 통제하기 위해, 반응시간에 정반응 여부를 고려하여 수정계산한 값인 역효율 점수(inverse efficiency scores, IES) (Townsend \& Ashby, 1983)로 반응시간을 변환하여 비 교하였다(Jung et al., 2015). 역효율 점수(IES)는 반응시간(RT)을 '1-오류반응 비율'로 나눈 값이다. 예를 들어 모두 정반응을 했을 경 우에는 RT를 '1-0'으로 나누기 때문에 IES와 RT가 동일한 값을 갖 지만, 오류반응의 비율이 $50 \%$ 일 경우에는 RT를 ' $1-0.5$ '로 나누기 
때문에 IES는 RT보다 2배 더 느린 값을 갖게 된다.

새로운 음운표상 인출과제 점수는 선행연구에 근거하여(Kim \& $\mathrm{Ha} 2014)$, 정확한 조음위치에서 정확하게 조음한 자음 및 모음에 각 1점씩을 부여한 후, 산출하여야 하는 총 음소에 대해 정확하게 산출한 음소가 차지하는 비율을 백분율로 구하였다. 따라서 본 연 구의 인출과제 점수는 자극어에 대한 음소 산출의 정확도(\%)를 의 미한다.

SPSS ver. 20.0 (IBM, Armonk, NY, USA)을 이용하여 다음과 같 은 방법으로 자료의 통계분석을 실시하였다. 집단(말소리장애아동 vs. 일반아동) 간 반응유형(Hit vs. Correct rejection)에 따른 새로 운 음운표상 판단과제의 정반응 점수와 반응시간(IES)에 유의한 차이가 있는지 알아보기 위해, 1 피험자 간 1피험자 내 혼합분산분 석을 실시하였다. 집단(말소리장애아동 vs. 일반아동) 간 새로운 음 운표상 인출과제의 정확도의 유의한 차이가 있는지 알아보기 위 해, 독립표본 $t$ 검정을 실시하였다. 주요변인과 새로운 음운표상 판 단과제와 인출과제 각각의 상관관계, 그리고 새로운 음운표상 판단 과제와 인출과제 간 상관관계 분석하기 위해, Pearson 상관분석을 실시하였다.

\section{연구 결과}

\section{집단 간 새로운 음운표상 판단과제 수행력 비교}

집단 간 새로운 음운표상 판단과제 정반응 점수 비교

새로운 음운표상 판단과제의 Hit 점수에서 말소리장애아동은 평균 11.28 (4.99)점, 일반아동은 평균 13.42 (2.34)점을 보였고, Correct rejection 점수에서 말소리장애아동은 평균 8.50 (3.79)점, 일반 아동은 평균 9.10 (3.12)점을 보였다(Figure 2). 이러한 차이가 통계 적으로 유의한지 알아보기 위하여 혼합분산분석을 실시한 결과, 집단 간 주효과 $\left(F_{(1,32)}=4.543, p<.05\right)$ 와 반응유형에 따른 주효과

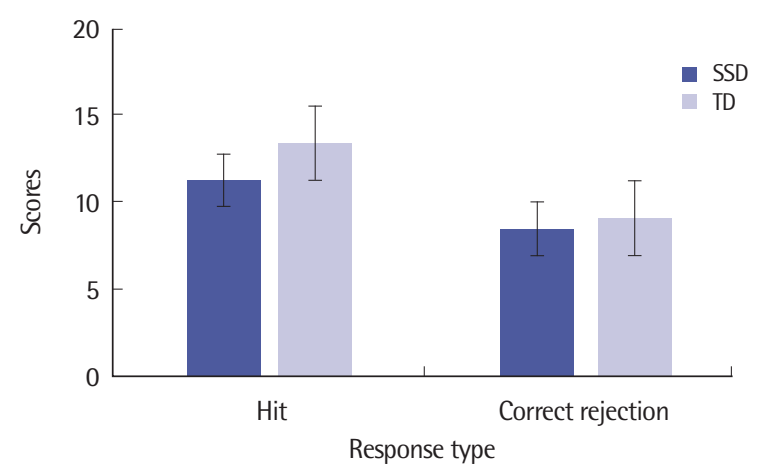

Figure 2. Scores from the new phonological representation task. SSD=speech sound disorders; TD=typically developing.
$\left(F_{(1,32)}=10.859, p<.05\right)$ 가 유의하였다. 그러나 집단과 반응유형 간 상호작용 효과는 유의하지 않았다 $\left(F_{(1,32)}=.504, p>.05\right)$.

\section{집단 간 새로운 음운표상 판단과제 반응시간 비교}

새로운 음운표상 판단과제의 반응시간(IES)은 Hit에서 말소리 장애아동 평균 7.95 (6.82)초, 일반아동 평균 4.31 (1.44)초로 나타났 고, Correct rejection에서 말소리장애아동 평균 14.25 (21.56)초, 일 반아동 평균 8.55 (7.71)초로 나타났다(Figure 3). 통계적 차이를 알 아보기 위하여 혼합분산분석을 실시한 결과, 집단 간 주효과 $\left(F_{(1,32)}\right.$ $=2.991, p>.05)$, 반응유형에 따른 주효과 $\left(F_{(1,32)}=3.362, p>.05\right)$, 그 리고 집단과 반응유형 간 상호작용효과 $\left(F_{(1,32)}=.129, p>.05\right)$ 모두 유의하지 않았다.

\section{집단 간 새로운 음운표상 인출과제 정확도 비교}

새로운 음운표상 인출과제에서 말소리장애아동은 평균 $3.38 \%$ (6.14\%), 일반아동은 평균 6.78\% (5.83\%)의 정확도를 보였다(Figure 4). 독립표본 $t$ 검정을 실시한 결과, 그 차이가 통계적으로 유의 하지 않았다 $(t=-1.606, p>.05)$.

\section{주요변인 간 상관관계}

주요변인인 월령, 수용어휘력, 자음정확도와 새로운 음운표상 판단과제 정반응 점수, 새로운 음운표상 인출과제 정확도 간 상관 관계를 분석하였다. 이때 새로운 음운표상 판단과제 정반응 점수 는 Hit와 Correct rejection을 합산하여 구하였다. 월령과 새로운 음 운표상 판단과제는 상관계수.466, 새로운 음운표상 인출과제는 상 관계수 .448로, 두 과제 모두 월령과 유의한 정적 상관관계가 있었 다 $(p<.05)$. 자음정확도와 새로운 음운표상 판단과제는 상관계수 .477 로 유의한 정적 상관관계가 있었지만 $(p<.05)$, 새로운 음운표 상 인출과제와는 상관관계가 유의하지 않았다(상관계수 $=.299$,

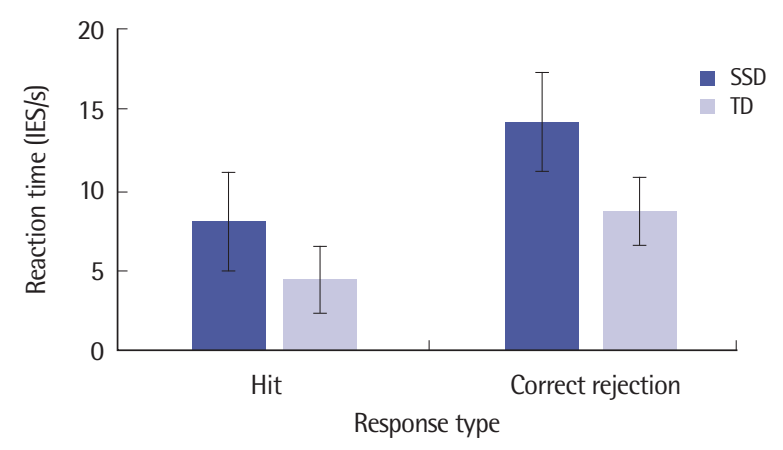

Figure 3. Reaction time (IES) on the new phonological representation task. $\mathrm{IES}=$ inverse efficiency score; $S S D=$ speech sound disorders; $T D$ = typically developing. 


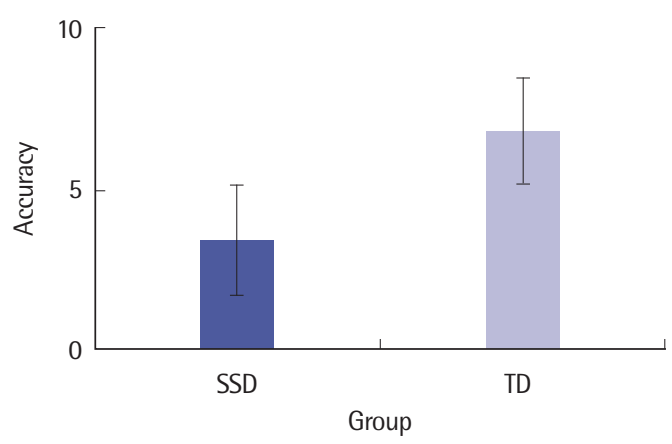

Figure 4. Accuracy on the new phonological representation retrieval task. $\mathrm{SSD}=$ speech sound disorders; $T \mathrm{D}=$ typically developing .

$p>$.05). 그리고 수용어휘력과 새로운 음운표상 판단과제와는 상관 관계가 유의하지 않았던 반면(상관계수 $=.328, p>.05$ ), 새로운 음 운표상 인출과제와는 상관계수 .487로, 유의한 정적 상관관계가 있 었다 $(p<.05)$. 마지막으로 새로운 음운표상 판단과제와 새로운 음 운표상 인출과제의 상관계수는 .397로, 상관은 낮지만 그 관계는 유의한 것으로 나타났다 $(p<.05)$.

\section{논의 및 결론}

본 연구에서는 말소리장애아동의 음운표상 결함이 초기 형성단 계부터 발생하였을 가능성을 전제하고, 새로운 음운표상의 저장과 인출능력에 대해 일반아동과 비교를 실시하고 관련요인들과의 관 계를 파악하고자 하였다. 그 결과 말소리장애아동은 일반아동보다 새로운 음운표상 판단과제의 정반응 점수가 유의하게 낮았으나, 판 단과제의 반응시간(IES)과 인출과제의 정확도에는 두 집단 간 유의 한 차이가 나타나지 않았다. 그리고 새로운 음운표상 판단과제 수 행력은 대상아동들의 월령 및 자음정확도와 유의한 상관관계가 있는 것으로, 인출과제 수행력은 대상아동들의 월령 및 수용어휘 력과 유의한 상관이 있는 것으로 분석되었다. 새로운 음운표상 판 단과제와 새로운 음운표상 인출과제 간 상관관계는 낮은 것으로 나타났다

새로운 음운표상 판단과제의 정반응 점수에 두 집단이 유의한 차이를 보였다는 연구결과는, 말소리장애아동이 일반아동보다 초 기 어휘 형성단계부터 음운표상을 정확하게 저장하는 데에 어려움 이 있음을 시사한다. 이것은 말소리장애아동이 일반아동보다 새로 운 음운표상의 학습에 어려움이 있다고 보고한 Sutherland (2006) 의 연구와 일치하는 결과이다. 음운표상의 초기 형성단계부터의 어 려움은 단지 이 시점의 결함만으로 끝나지 않을 것이다. 이와 더불 어 현재 장기기억 속에 보유하고 있는 음운표상의 질, 그리고 그것 에 접근, 인출하는 음운처리능력에도 결함을 초래할 수 있다.
본 연구에서는 새로운 음운표상 판단과제의 반응유형을 $\mathrm{Hit}$ 와 Correct rejection으로 분류하여 분석하였다. 그 결과 집단에 상관 없이 Hit 점수가 Correct rejection 점수보다 유의하게 높은 것이 확 인되었다. 이와 유사한 결과가 Claessen 등(2009)의 연구에서도 보 고된 바 있는데, 이것은 틀린 말소리가 옳은 말소리보다 청각적 민 감도가 낮기 때문에 나타난 결과로 설명된다. 정상성인의 경우에도 옳은 말소리는 청각적으로 익숙하기 때문에 민감하게 들려 그것의 정확성 여부를 쉽게 판단할 수 있는 반면, 틀린 말소리는 청각적으 로 익숙하지 않기 때문에 그것의 정확성 여부를 판단하는 데에 시 간이 오래 걸린다는 것이다. 본 연구에서는 이것이 반응시간의 차 이가 아닌 정반응 점수의 차이로 나타나, 아동의 경우 익숙하지 않 은 틀린 말소리를 판단하는 데에 성인처럼 더 오랜 시간이 걸릴 뿐 아니라 이것은 결국 오반응으로 이어질 수도 있다는 것을 알 수 있 었다. 그뿐만 아니라 집단과 반응유형 간 상호작용효과가 나타나지 않았다는 연구결과는 말소리장애아동과 일반아동 간 Correct rejection의 어려움에 대해 다른 양상을 보이지는 않는다는 것을 시사 한다. 즉, 말소리장애아동은 일반아동보다 새로운 음운표상을 판 단하는 능력이 떨어지기는 하지만, 과제를 수행할 때 직면한 어려 움은 일반아동과 질적으로는 다르지 않다는 것을 추측할 수 있다.

속도-정확성의 교환효과를 통제하기 위해 새로운 음운표상 판 단과제의 반응시간을 IES로 변환하여 분석했음에도 불구하고, 연 구결과 집단 간, 그리고 반응유형 간 반응시간(IES)에는 유의한 차 이가 없었다. 기술통계를 살펴보면 말소리장애아동은 Hit 평균 7.95 (6.82)초, Correct rejection 평균 14.25 (21.56)초, 일반아동은 Hit 평균 4.31 (1.44)초, Correct rejection 평균 8.55 (7.71)초의 반응 시간(IES)을 보였다. 즉 일반아동보다 말소리장애아동 집단에서, Hit보다 Correct rejection에서 평균적으로 반응시간(IES)이 긴 경 향이 있었다. 그런데 일반아동의 경우에도 Hit와 Correct rejection 평균이 각각 4.31 초와 8.55 초로, 반응시간이 상당히 긴 것을 알 수 있다. 특히 Correct rejection의 경우는 더욱 그러하다. 본 연구에서 사용한 새로운 음운표상은 일반아동에게도 처음 접하는, 익숙하 지 않은 소리자극이었다. 앞에서 익숙하지 않은 소리자극은 청각적 민감성이 떨어지기 때문에 그것을 파악하는 데에 오랜 시간이 걸린 다는 것을 언급한 바 있다. 아무리 여러 차례의 학습단계를 거쳤다 고 하더라도, 새로운 음운표상은 여전히 익숙하지 않은 소리자극 이기 때문에 일반아동들조차 그것의 정오 여부를 판단하는 데에 오랜 시간이 걸렸고, 이와 같은 이유로 집단 간 반응시간에 유의한 차이가 나타나지 않았을 가능성을 생각해볼 수 있다. 그러나 과제 수행을 위해 일반아동도 말소리장애아동만큼 오랜 시간을 필요로 하였지만, 결과적으로 그것의 정확성 여부는 일반아동이 유의하게 
더 잘 판단하였다는 점을 간과하여서는 안 될 것이다. 이와 같은 경 우 대상자들의 수행력 비교에 반응시간보다 정반응 점수가 보다 의 미 있는 정보를 제공하는 것으로 보인다. 따라서 유사한 과제라도 그 특성에 따라 좀 더 중점적으로 해석해야 할 변수가 달라질 수 있 기 때문에, 연구를 진행할 때에는 실시한 과제에 대한 명확한 이해 가 선행되어야 할 것이다.

새로운 음운표상 인출과제 정확도에서도 말소리장애아동과 일 반아동 간 차이가 유의하지 않았다. 정확도 평균은 말소리장애아 동 3.38\% (6.14\%), 일반아동 6.78\% (5.83\%)으로, 두 집단 모두 수행 력이 매우 저조하였다. 근본적으로 본 과제의 난이도가 대상아동 들에게 너무 높았던 것으로 판단된다. 대상아동 모두가 본 과제를 이처럼 어려워하였던 이유에 대해, 아동의 음운기억 수행능력의 한 계와 관련하여 생각해볼 수 있다. Park, Lee와 Kwon (2011)의 연구 에서 일반아동의 비단어 기억폭은 3 세 평균 3.17 (0.57)개, 4 세 평균 3.31 (0.47)개, 5세 평균 3.42 (0.67)개, 6세 평균 4.00 (0.72)개로 보고 되었다. 본 연구에서 7 분 내외의 시간 동안 아동들은 8 개의 새로운 음운표상을 기억하여야 했다. 각각의 음운표상을 그림과 함께 독 립적으로 제시하였지만 아동들에게는 8 개의 음운표상이 비단어 의 연속으로 여겨질 수 있고, 때문에 인출과제는 대상아동들의 기 억폭의 한계를 초과했을 것으로 추측된다.

덧붙여 새로운 음운표상 인출과제 시 흥미로웠던 점은 일부 아 동에서 음운표상 대신 학습단계에서 제시되었던 의미적 내용을 말 하는 경우가 관찰되었다는 것이다. 예를 들어 아동들은 "무서운 거", "착한 거", "예쁜 거", "딱딱한 거"와 같이 해당 그림의 의미를 이야기 하는 경우가 있었다. 학습단계에서 그림에 대한 음운표상은 6 차례나 반복 제시되었고, 특정 의미는 그림과 짝지어 1 차례만 제 시되었다는 점을 고려할 때, 새로운 단어의 의미는 말소리 정보보 다 훨씬 쉽게 기억 속에 저장될 수 있다는 것을 알 수 있다. 물론 "무 섭다", "착하다"와같은 의미는 아동이 이미 알고 있는 단어로 이루 어져있기 때문에 쉽게 기억이 될 것이다. 그러나 한 차례 접한 의미 보다 반복적으로 접한 새로운 말소리 처리에 더 어려움을 보였다는 본 연구의 결과는, 아동들의 어휘습득에 있어 음운처리능력의 중 요성에 대해 시사하는 바가 있다.

월령, 수용어휘력, 자음정확도와 새로운 음운표상 판단과제 및 인출과제의 상관관계 분석 결과, 월령은 두 과제 모두와 유의한 정 적 상관이 있는 것으로 나타났다. 이러한 결과는 연령이 높아짐에 따라 음운표상 판단과제 수행력이 향상되고(Claessen et al., 2009; Kim, Kwon, Jeong, Meng, \& Ha, 2013), 비단어 따라말하기 수행력 이 좋다(Lee et al., 2016)는 연구들과 맥락을 같이 한다. 본 연구의 경우 대상아동들의 연령이 $4,5,6$ 세로 한정되어 있었음에도 불구
하고 과제의 수행력과 월령 간 유의한 상관이 있었던 것으로 미루 어, 음운표상의 처리능력은 해당 연령대에서 활발하게 발달한다는 것을 알 수 있다. 또한 음운표상 판단과제 수행력은 자음정확도와 도 유의한 상관관계가 있었다. 이러한 결과는 말소리장애아동의 문 제가 단지 조음산출과 같은 말초적 처리단계의 문제가 아니라, 보 다 중추적인 요인, 즉 저장된 음운표상의 질과 관련될 것일 가능성 을 제시한다. 그리고 새로운 음운표상 인출과제 정확도는 수용어휘 력과 유의한 상관이 있었다. 본 연구에서는 대상자들의 어휘력을 통제하는 대신 새로운 음운표상의 단어유사성을 낮춰 대상자들의 장기기억에 그것과 유사한 형태의 단어가 저장되어 있을 가능성을 최소화하고자 하였다. 그럼에도 불구하고 수용어휘력과 새로운 음 운표상 인출능력에 상관관계가 나타난 것은 어려운 실험과제에 대 한 대상자들의 노력이 반영된 결과로 추측된다. 난이도가 매우 높 았던 인출과제의 경우 대상자들은 본인이 가지고 있는 지식을 총 동원하여 과제를 성공적으로 수행하기 위해 노력했을 것이다. 즉 대상자들은 방금 전 학습하였던 자극어와 유사한 형태의 어휘를 떠올리며, 음운완충기(phonological buffer)에서 새로운 음운표상 의 정보를 유지하려는 하향접근적 노력(top-down approach)을 하 였을 것으로 추측된다. 음운처리과제 수행에는 상향적 접근뿐 아 니라 하향적 접근 능력 또한 요구된다는 것은 이미 여러 연구들에 서 밝혀진 바 있다(Lee et al., 2016). 나아가 본 연구의 결과는 음운 기억 수행능력의 한계에 직면하였을 때 이러한 하향적 접근 노력이 보다 활발하게 작용한다는 것을 시사한다.

마지막으로 새로운 음운표상 판단과제와 새로운 음운표상 인출 과제 간 수행력은 낮은 상관관계를 나타내었다. 이것은 음운표상의 접근과 산출은 서로 다른 처리과정으로 이루어져 있다는 Stackhouse와 Wells (1997)의 주장을 지지하는 결과로 여겨진다. 또한 본 연구와 대상집단은 다르지만, 난독증 아동에서 말산출과 말지각 결함 간 연관성이 없다는 Vellutino, Fletcher, Snowling과 Scanlon (2004)의 연구, 언어발달장애아동에서 음운표상 판단과제와 이름 대기과제 수행력 간 상관관계가 없다는 Claessen과 Leitão (2012) 의 연구와도 맥락을 같이 하는 것으로 보인다. 따라서 음운표상의 질이 정상적이더라도 인출과정에 어려움을 보일 수 있고 그 반대의 경우 또한 가능하다는 것을 염두에 두고, 음운표상과 관련하여 수 용과 산출 두 가지 측면 모두에서 평가와 중재가 독립적으로 이루 어져야할 것이다.

이상과 같은 해석을 통해 새로운 음운표상 인출이 가능할 정도 로 새 단어를 완전히 학습하기 위해서는, 본 연구의 실험과정처럼 새 단어의 의미와 소리정보에 단순하게 반복 노출되는 것 이상의 무엇이 필요하다는 것을 짐작할 수 있다. 이와 관련하여 Lee 등(2016) 
의 연구에서는 '시연(rehearsal)' 중요성을 강조하였다. 즉 제시된 항 목들을 반복하여 능동적으로 암송함으로써 음운단기기억을 촉진 할 수 있고, 이러한 시연과정을 통해 단기기억 내 정보들이 유지되 고 재구조화되어 장기기억까지 연장될 수 있다는 것이다. 더 나아 가 Lee 등(2016)은 소리 내어 반복하는 외현적 시연이 소리 내지 않 고 마음속으로 반복하는 내현적 시연보다 학령전기 아동의 기억력 향상에 도움이 된다고 제안하였다. Ellis와 Beaton (1993)의 연구에 서도 외현적 시연은 음운루프에 들어온 음운정보를 순환시킴으로 써 임시적 음운표상을 강화해 주는 역할을 하는 것으로 보고되었 다. 따라서 본 연구에서 실시하였던 것과 같은 음운표상에 대한 수 동적 경험은 새로운 음운표상을 완전하게 습득하게 하는 데에 분 명 제한이 있는 것으로 보인다. 새로운 음운표상의 인출능력을 좀 더 타당하게 평가하기 위해, 추후 연구에서는 시연활동과 같은 보 다 능동적 경험을 통한 실험이 이루어져야 할 것이다.

말소리장애아동의 음운표상 결함이 초기 형성단계부터 발생할 가능성을 제시하였다는 점에서 본 연구결과는 의의가 있다. 이러 한 결과는 말소리장애아동의 경우 새로운 단어를 처음 접할 때 그 것의 소리정보를 명확하게 저장하는 데에 별도의 노력이 필요하다 는 것을 시사하며, 이는 분명 말소리장애의 치료 방향성에 의미하 는 바가 있을 것이다. 음운표상을 명확하게 저장시키기 위한 방법 으로 소리자극에 대한 보다 반복된 경험, 더 나아가 수동적 노출이 아닌 능동적 경험의 반복을 생각해볼 수 있다. 이러한 연구의 의의 에도 불구하고 본 연구는 방법상 몇몇 제한점 또한 가지고 있다. 그 중 하나로 학습단계에서 대상아동들의 행동을 일정하게 통제하지 못하였다는 점을 들 수 있다. 새로운 음운표상의 학습이 진행되는 7 분여 동안 아동들의 집중력에는 개인차가 있었다. 또한 일부 아동, 특히 일반아동의 몇 명은 학습과정 동안 자발적으로 외현적 혹은 내현적 시연을 활용하는 것이 관찰되었다. 집중력과 시연은 새로운 음운표상 형성능력에 영향을 미치는 요인들이다. 따라서 추후연구 에서는 이러한 대상자 변인들을 통제하여 좀 더 체계화된 실험을 진행하여야 할 것이다. 무엇보다 본 연구는 대상자의 수가 적었다는 제한점을 지닌다. 서론에서도 언급하였듯이 말소리장애집단은 단 일한 집단이 아니라 여러 이질적인 집단들이기 때문에, 새로운 음 운표상의 형성 결함이 모든 말소리장애아동에서 나타난다고 단정 할 수 없다. 대상자 수를 많이 하여 대규모 연구를 실시한다면, 말소 리장애집단 내에서도 새로운 음운표상 형성능력에 다양한 수행차 이가 나타날 가능성을 배제할 수 없다. 이러한 차이는 음운표상 또 는 음운처리와 관련하여 말소리장애집단을 하위집단들로 분류하 는 데에, 더 나아가 말소리장애의 다양한 일차적 원인에 접근해가 는 데에 의미 있는 정보를 제공할 것이다. 따라서 본 연구결과를 바
탕으로, 보다 체계적인 대규모 연구가 추후 필요할 것으로 보인다.

\section{REFERENCES}

American Psychiatric Association. (2013). Diagnostic and Statistical Manual of Mental Disorders-5 (DSM-5). Washington, DC: Author.

Anthony, J. L., Williams, J. M., Aghara, R. G., Dunkelberger, M., Novak, B., \& Mukherjee, A. D. (2010). Assessment of individual differences in phonological representation. Reading and Writing, 23, 969-994.

Bruyer, R., \& Brysbaert, M. (2011). Combining speed and accuracy in cognitive psychology: is the inverse efficiency score (IES) a better dependent variable than the mean reaction time (RT) and the percentage of errors (PE)? Psychologica Belgica, 51, 5-13.

Carroll, J. M., \& Snowling, M. J. (2004). Language and phonological skills in children at high risk of reading difficulties. Journal of Child Psychology and Psychiatry, 45, 631-640.

Claessen, M., \& Leitão, S. (2012). The relationship between stored phonological representations and speech output. International Journal of SpeechLanguage Pathology, 14, 226-234.

Claessen, M., Heath, S., Fletcher, J., Hogben, J., \& Leitão, S. (2009). Quality of phonological representations: a window into the lexicon? International Journal of Language \& Communication Disorders, 44, 121-144.

Ellis, N., \& Beaton, A. (1993). Factors affecting the learning of foreign language vocabulary: imagery keyword mediators and phonological shortterm memory. Quarterly Journal of Experimental Psychology, 46, 533-558.

Jung, I. K., Choi, S. Y., \& Ha, J. W. (2015). Internal awareness of phonological representation in children with speech sound disorders. Communication Sciences and Disorders, 20, 49-59.

Kim, H. K., \& Kang, B. M. (1997). Frequency analysis of the use of Hangul. Seoul: Korea University, Research Institute of Korea Studies.

Kim, N. Y., \& Ha, J. W. (2014). Phonological representations in children with articulation and phonological disorders. Communication Sciences \& Disorders, 19, 226-237.

Kim, N. Y., Kwon, S. N., Jeong, I. K., Meng, H. S., \& Ha, J. W. (2013). Development of phonological representation in typically developing preschoolers. Communication Sciences \& Disorders, 18, 330-340.

Kim, S. J., \& Shin, J. Y. (2015). Speech sound disorders. Seoul: Sigma Press.

Kim, Y. T., \& Shin, M. J. (2004). Urimal test of articulation and phonology (UTAP). Seoul: Hakjisa.

Kim, Y. T., Hong, G. H., Kim, K. H., Jang, H. S., \& Lee, J. Y. (2009). Receptive 
\& expressive vocabulary test (REVT). Seoul: Seoul Community Rehabilitation Center.

Kwak, K. C., Oh, S. W., \& Kim, C. T. (2011). Korean-Wechsler Intelligence Scale for Children-IV (K-WISC-IV). Seoul: Hakjisa.

Kwon, M. (2004). Evolution of aphasia profile and auditory comprehension ability in Wernicke's aphasia (Doctoral dissertation). Ewha Womans University, Seoul, Korea.

Lee, S. J., Ha, J. W., Koo, M. M., Hwang, Y. M., \& Pyun, S. B. (2016). Delayed non-word according to the rehearsal conditions in 6- to 7-year-old children. Communication Sciences \& Disorders, 21, 69-83.

Maillart, C., Schelstraete, M. A., \& Hupet, M. (2004). Phonological representations in children with SLI: a study of French. Journal of Speech, Language, and Hearing Research, 47, 187-198.

Park, H. J., Lee, M. K., \& Kwon, D. H. (2011). Characteristics of auditory word memory of normal children aged between 3 and 6 . Journal of Speech-Language \& Hearing Disorder, 20, 183-203.

Stackhouse, J., \& Wells, B. (1997). Children's speech and literacy difficulties: a psycholinguistic framework. San Diego, CA: Singular Publishing Group.

Sutherland, D. E. (2006). Phonological representations, phonological awareness, and print decoding ability in children with moderate to severe speech impairment (Doctoral dissertation). University of Canterbury, Christchurch, New Zealand.

Sutherland, D., \& Gillon, G. T. (2005). Assessment of phonological representations in children with speech impairment. Language, Speech, and Hearing Services in Schools, 36, 294-307.

Sutherland, D., \& Gillon, G. T. (2007). Development of phonological representations and phonological awareness in children with speech impairment. International Journal of Language \& Communication Disorders, 42, 229-250.

Townsend, J. T., \& Ashby, F. G. (1983). Stochastic modeling of elementary psychological processes. Cambridge: Cambridge University Press.

Vellutino, F. R., Fletcher, J. M., Snowling, M. J., \& Scanlon, D. M. (2004). Specific reading disability (dyslexia): what have we learned in the past four decades? Journal of Child Psychology and Psychiatry, 45, 2-40.

Walley, A. C. (1993). The role of vocabulary development in children's spoken word recognition and segmentation ability. Developmental Review, 13, 286-350. 


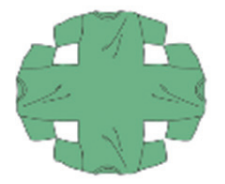

니븐

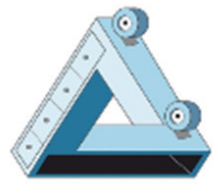

히눅

너겝 방목


Appendix 2. 새로운 음운표상에 대한 학습 제시어 목록

\begin{tabular}{|c|c|c|c|}
\hline \multicolumn{4}{|c|}{ 연습 항목 } \\
\hline 목표 단어 & 학습 목록 & 목표 단어 & 학습 목록 \\
\hline \multirow[t]{6}{*}{ 니븐 } & 1) 니븐 & \multirow[t]{6}{*}{ 히눅 } & 1) 히눅 \\
\hline & 2) 이것은 니븐이야 & & 2) 이것은 히눅이야 \\
\hline & 3) 멋진 니븐 & & 3) 큰 히눅 \\
\hline & 4) 니븐은 초록색이야 & & 4) 히눅은 세모야 \\
\hline & 5) 니븐은 따뜻해 & & 5) 히눅은 바퀴가 있어 \\
\hline & 6) 니븐은 부드러워 & & 6) 히눅은 딱딱해 \\
\hline \multicolumn{4}{|c|}{ 본 항목 } \\
\hline 목표 단어 & 학습 목록 & 목표 단어 & 학습 목록 \\
\hline \multirow[t]{6}{*}{ 너겝 } & 1) 너겝 & \multirow[t]{6}{*}{ 니버껑 } & 1) 니버껑 \\
\hline & 2) 이것은 너겝이야 & & 2) 이것은 니버껑이야 \\
\hline & 3) 작은 너겝 & & 3) 예쁜 니버껑 \\
\hline & 4) 너겝은 귀여워 & & 4) 니버겅은 웃고 있어 \\
\hline & 5) 너겝은 콧수염이 있어 & & 5) 니버껑은 치마를 입어 \\
\hline & 6) 너겝은 갈색이야 & & 6) 니버껑은 손으로 걸어 \\
\hline \multirow[t]{6}{*}{ 데릅뜹 } & 1) 데릅뜹 & \multirow[t]{6}{*}{ 머겜밍 } & 1) 머겜밍 \\
\hline & 2) 이것은 데릅뜹이야 & & 2) 이것은 머겜밍이야 \\
\hline & 3) 무서운 데릅뜹 & & 3) 긴 머겜밍 \\
\hline & 4) 데릅뜹은 네모야 & & 4) 머겜밍은 뚱뚱해 \\
\hline & 5) 데릅뜹은 부리가 있어 & & 5) 머겜밍은 차가워 \\
\hline & 6) 데릅뜹은 날아다녀 & & 6) 머겜밍은 굴러다녀 \\
\hline 두빕 & $\begin{array}{l}\text { 1) 두빕 } \\
\text { 2) 이것은 두빕이야 } \\
\text { 3) 딱딱한 두빕 } \\
\text { 4) 두빕은 파랑색이야 } \\
\text { 5) 두빕은 튼튼해 } \\
\text { 6) 두빕은 달리기를 잘해 }\end{array}$ & 머툴 & $\begin{array}{l}\text { 1) 머툴 } \\
\text { 2) 이것은 머툴이야 } \\
\text { 3) 착한 머툴 } \\
\text { 4) 머툴은 주황색이야 } \\
\text { 5) 머툴은 입을 벌리고 있어 } \\
\text { 6) 머툴은 발로 걸어다녀 }\end{array}$ \\
\hline
\end{tabular}

Appendix 3. 새로운 음운표상에 대한 조작된 자극어 목록

\begin{tabular}{ccccc}
\hline & & & \multicolumn{3}{c}{ 조작된 자극어 } \\
\cline { 2 - 4 } & 목표 단어 & 첫 자음 조작 & 첫 모음 조작 & 첫 음절 조작 \\
\hline 연습항목 & 니븐 & 디븐 & 누븐 & 두븐 \\
& 히눅 & 시눅 & 후눅 & 수눅 \\
본 항목 & 더겝 & 나겝 & 다겝 \\
& 너겝 & 디버껑 & 누버껑 & 두버껑 \\
& 니버껑 & 떼릅뜹 & 도릅뜹 & 또릅뜹 \\
& 데릅뜹 & 버겜밍 & 마겜밍 & 바겜밍 \\
& 머겜밍 & 누빕 & 디빕 & 니빕 \\
& 두빕 & 버툴 & 마툴 & 바툴 \\
& 머툴 & & &
\end{tabular}




\section{국문초록}

\section{말소리장애아동의 새로운 음운표상 형성 능력}

배세령 $\cdot$ 하지완 $2.3 \cdot$ 구민모 ${ }^{4}$ 황유미 ${ }^{3.5} \cdot$ 편성범6,7

${ }^{1}$ 대구대학교 대학원 재활과학과 언어치료전공, ${ }^{2}$ 대구대학교 언어치료학과, ${ }^{3}$ 대구대학교 국제재활과학연구소, ${ }^{4}$ 고려대학교 안암병원 의생명연구센터, ${ }^{5}$ 고려대학교 언어정보연구소, ${ }^{6}$ 고려대학교 의과대학 재활의학교실, ${ }^{7}$ 고려대학교 안암병원 융합뇌신경연구센터

배경 및 목적: 본 연구에서는 말소리장애아동의 음운표상 결함이 초기 형성단계부터 발생하였을 가능성을 전제하고, 새로운 음운표 상의 저장과 인출능력에 대해 일반아동과 비교를 실시하고 관련요인들과의 관계를 파악하고자 하였다. 방법: $4,5,6$ 세 말소리장애 아 동 14 명과 일반 아동 19 명을 대상으로, 새로운 단어에 대해 의미와 함께 음운표상을 학습하는 학습단계를 거친 후 새로운 음운표상 판 단과제와 인출과제를 실시하였다. 새로운 음운표상 판단과제에 대해서는 정반응 점수와 반응시간을, 새로운 음운표상 인출과제에 대 해서는 산출 정확도를 분석하여, 집단 간 비교를 실시하였다. 월령, 자음정확도, 수용어휘력과 새로운 음운표상 판단과제 및 인출과제 와의 상관관계, 그리고 새로운 음운표상 판단과제와 인출과제 간 상관관계 분석을 실시하였다. 결과: 말소리장애아동은 일반아동보다 새로운 음운표상 판단과제의 정반응 점수가 유의하게 낮았으나, 판단과제의 반응시간(IES)과 인출과제의 정확도에는 두 집단 간 유의 한 차이가 나타나지 않았다. 새로운 음운표상 판단과제 수행력은 대상아동들의 월령 및 자음정확도와 유의한 상관관계가 있는 것으 로, 인출과제 수행력은 대상아동들의 월령 및 수용어휘력과 유의한 상관이 있는 것으로 분석되었다. 논의 및 결론: 말소리장애아동의 음운표상 결함이 초기 형성단계부터 발생할 가능성을 제시하였다는 점에서 본 연구결과는 의의가 있다. 말소리장애아동의 경우 새로 운 단어를 처음 접할 때 그것의 소리정보를 명확하게 저장하려는 별도의 노력이 필요할 것이며, 이는 말소리장애의 치료 방향성에 시사 하는 바가 있을 것이다.

핵심어: 새로운 음운표상 판단과제, 새로운 음운표상 인출과제, 말소리장애

이 논문은 2013년 정부(교육부)의 재원으로 한국연구재단의 지원을 받아 수행된 연구임(NRF-2013S1A3A2043454).

\section{참고문헌}

곽금주, 오상우, 김청택(2011). 웩슬러 아동용 지능검사(K-WISC-IV). 서울: 학지사.

권미선(2004). 베르니케실어증 환자의 실어유형 및 청각언어이해능력의 변화특성. 이화여자대학교대학원 박사학위논문. 김나연, 권상남, 정일권, 맹현수, 하지완(2013). 학령전기 일반 아동의 음운표상 발달. 언어청각장애연구, 18, 330-340.

김나연, 하지완(2014). 조음음운장애아동과 일반아동의 음운표상의 질과 음운표상 부호화 능력 비교. 언어청각장애연구, 19, 226-237.

김수진, 신지영(2015). 말소리장애. 서울: 시그마프레스.

김영태, 신문자(2004). 우리말 조음·음운평가(U-TAP). 서울: 학지사.

김영태, 홍경훈, 김경희, 장혜성, 이주연(2009). 수용·표현어휘력검사(REVT). 서울: 서울장애인종합복지관.

김흥규, 강범모(1997). 한글 사용빈도의 분석. 서울: 고려대학교 민족문화연구소.

박현정, 이무경, 권도하(2011). 3-6세 정상 아동의 청각단기기억력 특성. 언어치료연구, 20, 183-203.

이석정, 하지완, 구민모, 황유미, 편성범(2016). 6, 7세 아동의 시연조건에 따른 지연 비단어따라말하기 능력 비교. 언어청각장애연구, 21

정일권, 최선영, 하지완(2015). 조음음운장애아동과 일반아동의 음운표상 내적 인식능력 비교. 언어청각장애연구, 20, 48-59. 